\title{
Anxiety-Related Mechanisms of Respiratory Dysfunction in a Mouse Model of Rett Syndrome
}

\author{
Jun Ren, Xiuqing Ding, Gregory D. Funk, and John J. Greer \\ Department of Physiology, Centre for Neuroscience, Women and Children's Health Research Institute, University of Alberta, Edmonton, Alberta, Canada \\ T6G 2E1
}

Rett syndrome (RTT) is a severe neurological disorder that is associated with mutations in the methyl-CpG binding protein 2 (MECP2) gene. RTT patients suffer from mental retardation and behavioral disorders, including heightened anxiety and state-dependent breathing irregularities, such as hyperventilation and apnea. Many symptoms are recapitulated by the Mecp2-null male mice (Mecp2-ly $)$. To characterize developmental progression of the respiratory phenotype and explore underlying mechanisms, we examined $M e c p 2^{-/ y}$ and wild-type (WT) mice from presymptomatic periods to end-stage disease. We monitored breathing patterns of unrestrained mice during wake-sleep states and while altering stress levels using movement restraint or threatening odorant (trimethylthiazoline). Respiratory motor patterns generated by in situ working heart-brainstem preparations (WHBPs) were measured to assess function of brainstem respiratory networks isolated from suprapontine structures. Data revealed two general stages of respiratory dysfunction in $M e c p 2^{-1 y}$ mice. At the early stage, respiratory abnormalities were limited to wakefulness, correlated with markers of stress (increased fecal deposition and blood corticosterone levels), and alleviated by antalarmin (corticotropin releasing hormone receptor 1 antagonist). Furthermore, the respiratory rhythm generated by WHBPs was similar in WT and Mecp $2^{-1 y}$ mice. During the later stage, respiratory abnormalities were evident during wakefulness and sleep. Also, WHBPs from Mecp $2^{-1 y}$ showed central apneas. We conclude that, at early disease stages, stress-related modulation from suprapontine structures is a significant factor in the Mecp $2^{-1 y}$ respiratory phenotype and that anxiolytics may be effective. At later stages, abnormalities of brainstem respiratory networks are a significant cause of irregular breathing patterns and central apneas.

\section{Introduction}

Rett syndrome (RTT) is a severe neurological disorder that is frequently (80-90\%) associated with mutations in the methylCpG binding protein 2 (MeCP2) gene (for review, see Neul and Zoghbi, 2004). The conventional view that loss of MeCP2 during a critical developmental window causes irreversible changes in brain structure and cellular function has been significantly modified with a striking reversal of phenotype when Mecp2 expression is reactivated in an inducible transgenic mouse model (Guy et al., 2007; Cobb et al., 2010; Guy et al., 2011; Lioy et al., 2011). Patients with RTT appear normal at birth but progressively suffer from a number of behavioral disorders, including severe breathing irregularities that can be highly variable, both among affected individuals and within individuals, depending, for example, on the level of behavioral arousal. The fact that patients experience extended periods of normal breathing (e.g., during sleep) suggests that the

Received June 21, 2012; revised Sept. 17, 2012; accepted Sept. 20, 2012.

Author contributions: J.R. and J.J.G. designed research; J.R., X.D., and G.D.F. performed research; J.R., X.D., and J.J.G. analyzed data; J.R., G.D.F., and J.J.G. wrote the paper.

This work was supported by the International Rett Syndrome Foundation (IRSF), the Ontario Rett Syndrome Foundation, the Canadian Institutes of Health Research, and the Women and Children's Health Research Institute. J.R. received a fellowship from IRSF. J.J.G. and G.D.F. are Alberta Innovates funded scientists. We thank Sandra Kelly for technical help.

Correspondence should be addressed to Dr. John J. Greer, 3-020M Katz Building, University of Alberta, Edmonton, Alberta, Canada T6G 2E1. E-mail: john.greer@ualberta.ca.

DOI:10.1523/JNEUROSCI.2951-12.2012

Copyright $\odot 2012$ the authors $\quad 0270-6474 / 12 / 3217230-11 \$ 15.00 / 0$ basis for the respiratory dysfunction is not necessarily within respiratory rhythm generating centers per se. Rather, abnormal respiratory rhythm could be attributable to state-dependent, descending drive to brainstem respiratory networks. Here we test this hypothesis using male mice $\left(M e c p 2^{-/ y}\right)$ that lack the Mecp2 gene product and have clear, progressive respiratory dysfunction as part of their phenotype (for review, see Katz et al., 2009). We focused on the relationship between anxiety levels and respiratory abnormalities because RTT patients have frequent episodes of heightened anxiety and an abnormal physiological response to stress (Sansom et al., 1993; Hagberg, 2002; Mount et al., 2002; Axelrod et al., 2006). Mouse models of RTT similarly show increased anxiety-like behavior (Moretti and Zoghbi, 2006; Fyffe et al., 2008) and an altered stress hormone system (Nuber et al., 2005; McGill et al., 2006; Braun et al., 2012).

We assessed central respiratory control mechanisms by examining individual mice and/or cohorts of mice over a wide development window that covered presymptomatic periods through to end-stage disease. Using whole-body plethysmography, we monitored breathing patterns as well as hypoxic and hypercapnic ventilatory responses in $M e c p 2^{-/ y}$ and wild-type (WT) mice at different sleep-wake states while systematically altering the levels of stress-related signaling. Furthermore, we tested whether blockade of stress-related signaling could reverse respiratory instabilities and stabilize rhythm. In addition, we compared at different ages rhythmic respiratory activity generated by in situ preparations from WT and $M e c p 2^{-/ y}$ mice to assess the function 
of brainstem respiratory networks when they are isolated from the influence of descending suprapontine inputs. Collectively, the data demonstrate that Mecp $2^{-/ y}$ mice experience two general stages of respiratory dysfunction through their lifespan. Stressrelated modulation of respiratory pattern from suprapontine structures accounts for a significant component of the respiratory phenotype during the early stage of the disease. In the later stage, the respiratory phenotype is dominated by the development of functional abnormalities within brainstem respiratory networks.

\section{Materials and Methods}

Animals. All experimental procedures were approved by the University of Alberta, Faculty of Medicine and Dentistry Animal Welfare Committee. Mecp2 heterozygous female (Mecp2 $2^{\text {tml-1Jae }}$ ) (Chen et al., 2001) and WT male mice were obtained from the Mouse Regional Resource Center (University of California Davis, Davis, CA), and a colony was established at the University of Alberta. B6.129 Mecp $2^{-/ y}$ and WT $\left(M e c p 2^{+/ y}\right)$ mice from within the same litter were processed together for comparisons.

Plethysmographic measurements. Measurements from unrestrained mice were performed in whole-body, Plexiglas plethysmographs that had inflow and outflow ports for the continuous delivery of a steady flow (300 $\mathrm{ml} / \mathrm{min}$ ) of fresh air and removal of expired carbon dioxide. Custom made Plexiglas chambers of various sizes were used to accommodate animals. The large chamber had a volume of $260 \mathrm{ml}$, a diameter of $5 \mathrm{~cm}$, and a length of $13 \mathrm{~cm}$. The small chamber had a volume of $50 \mathrm{ml}$, a diameter of $3.5 \mathrm{~cm}$, and a length of $6 \mathrm{~cm}$. Recordings were made in the large chamber (in which mice could move freely) except when indicated. Plethysmographic recordings commenced $\sim 20$ min after placing the mice in the chamber. Pressure changes were detected with a pressure transducer (model DP 103; Validyne), signal conditioner (CD-15; Validyne), an analog-to-digital board (Digidata 1322A), and data acquisition (Axoscope) and analysis (Clampfit) software (Molecular Devices). It should be noted that our plethysmographic recording setup is effective for studying respiratory frequency $\left(f_{\mathrm{R}}\right)$ and detection of apneas. However, it is not designed for precise quantification of tidal volume $\left(V_{\mathrm{T}}\right.$; milliliters per grams). The physical principle underlying whole-body plethysmography is the detection of pressure changes in the chamber resulting from the heating and humidification of inspired gas. However, tidal volume measurements may also be influenced by gas compression effects related to the airway resistance. Because of these limitations, our whole-body plethysmographic system only provided semiquantitative measurements of $V_{\mathrm{T}}$ and detection of changes relative to control state. As a result, our measurements of minute ventilation $\left(V_{\mathrm{E}}\right.$; milliliters per minutes per grams), which equates to $f_{\mathrm{R}} \times V_{\mathrm{T}}$, are also semiquantitative and only reported relative to control. An apnea is defined as the absence of airflow for a period equivalent or greater than two complete respiratory cycles. The chemoreceptive responses ( $1 \mathrm{~min}$ after gas exchange) to changed $\mathrm{O}_{2}$ or $\mathrm{CO}_{2}$ were assessed by switching from room air to hypoxia $\left(8 \% \mathrm{O}_{2}\right)$ or hypercapnia $\left(5 \% \mathrm{CO}_{2}\right)$ with a flow rate of $3 \mathrm{~L} / \mathrm{min}$. Note that the flow of room air was first elevated to $3 \mathrm{~L} / \mathrm{min}$, animals were allowed to settle, and then the gas composition was changed without any change in airflow or any other noticeable event that was coincident with the gas switching. It took $\sim 12 \mathrm{~s}$ for the new gas to equilibrate within the large chamber, as confirmed by measurements of oxygen content with Oxychek instrumentation (Critikon). Rectal temperature was measured before and after plethysmographic recordings (model 8402-10 thermistor; Cole-Parmer Instrument Company). Body temperature was maintained in both WT and Mecp $2^{-1 y}$ mice during the $1-2 \mathrm{~h}$ recording sessions without a significant change $\left(<0.2^{\circ} \mathrm{C}, n=3\right.$ each $)$.

Radio telemetry for monitoring sleep-wake states. Cerebral cortical electroencephalogram (EEG) and neck electromyogram (EMG) signals were measured by telemetry and used to identify and confirm the reliability of visual inspection of sleep-wake states in Mecp $2^{-l y}$ and WT mice. Combinations of high-amplitude EMG activity and low-amplitude EEG indicated wakefulness. Quiet wakefulness was associated with irregular EEG, and active wakefulness (animals actively walking and turning within the chamber) was associated with regular theta rhythm EEG. Lower levels of EMG activity with regular theta $(5-9 \mathrm{~Hz})$ rhythm corresponded to rapid eye movement (REM) sleep. Lower levels of EMG activity with highamplitude delta (1-4 Hz) waves were classified as non-rapid eye movement (NREM) sleep (Steriade et al., 1993; Brankack et al., 2010). With visual inspection only, one could not reliably differentiate REM from NREM sleep. Thus, we only visually separate the sleep from wake state. Mice were anesthetized with isoflurane $\left(0.5-1 \%\right.$ in $\left.5 \% \mathrm{CO}_{2}-95 \% \mathrm{O}_{2}\right)$ and instrumented with F20 radio telemetry probes (Data Sciences International) as described previously (Stephenson et al., 2001). Briefly, midline incisions were made in the scalp and abdomen to expose the skull and peritoneal cavity, respectively. Body temperature was maintained at $37^{\circ} \mathrm{C}$ using a heating pad. The radio transmitter was inserted into the peritoneal cavity and loosely sutured to the rectus abdominus muscle. The electrode leads from the implant were tunneled from the peritoneal cavity and led subcutaneously to the head. The muscle and skin of the abdomen were closed. An EMG electrode was sutured to the neck muscle. A hole was drilled into the skull, and an EEG electrode was placed $\sim 2 \mathrm{~mm}$ to the right and $2 \mathrm{~mm}$ anterior to bregma. Dental acrylic was used to anchor the electrodes to the skull. The mice were allowed to recover for at least 1 week before recordings were made. Animals were placed in the plethysmograph from where transmitted neck EMG and EEG signals were recorded continuously while monitoring respiration. Mice slept $\sim 30 \%$ of the $1-2 \mathrm{~h}$ period per day in the plethysmograph $(n=3$ each for WT and $M e c p 2^{-l y}$ ).

Measurement of stress-related behavior and serum corticosterone. Stressrelated behavior was monitored in conjunction with recordings of respiratory patterns. Indication of stress was monitored by the accepted criteria of counting fecal boli deposited in the first $10 \mathrm{~min}$ after a mouse is put into the plethysmographic chamber (Calvo-Torrent et al., 1999). In addition, serum corticosterone measurements (collected between 12:00 P.M. and 2:00 P.M.) were obtained from WT and Mecp $2^{-/ y}$ after exposure to a stress-inducing protocol for $1 \mathrm{~h}$. Specifically, corticosterone levels were obtained from four experimental groups: (1) in the home cage or large chamber ( $260 \mathrm{ml}$ volume); (2) in the more restraining confines of the small recording chamber ( $50 \mathrm{ml}$ volume); (3) exposure to $0.5 \mu \mathrm{l}$ trimethylthiazoline (TMT) (Phero Tech) (TMT is extracted from fox feces and is an experimental model proven to cause acute anxiety and increased corticosterone levels (Blanchard et al., 2003; Vendruscolo et al., 2006) in the large chamber; and (4) after the administration of the corticotropin releasing hormone receptor 1 (CRHR1) antagonist antalarmin (10 mg/kg, i.p.), animals were put back to the home cage for 20 min and then put into the large chamber or small chamber for $1 \mathrm{~h}$. Antalarmin was dissolved in $100 \%$ DMSO at a concentration of 60 $\mathrm{mg} / \mathrm{ml}$ and then diluted with saline to a $3 \mathrm{mg} / \mathrm{ml}$ solution for injection. Mice were killed by rapid decapitation, and the trunk blood was collected in prechilled tubes containing EDTA. The blood was centrifuged for 10 min, and serum was collected and frozen at $-80^{\circ} \mathrm{C}$ until analyzed. Total serum corticosterone concentration was measured using ELISA kits as per the instructions of the manufacturer (Immunodiagnostics Systems). In each assay, duplicate wells were assigned for each sample. A microplate reader was used to measure signal intensity from the wells. A standard curve was generated using the KC Junor software (Bio-Tek).

In situ working heart-brainstem preparation. The in situ decerebrated working heart-brainstem preparation (WHBP) generates a robust respiratory discharge (Paton, 1996) and is well suited for analyzing basic respiratory rhythmogenesis in reduced adult rodents without modulatory state-dependent inputs from suprapontine structures. We followed our previously described protocol (Ren et al., 2006). Briefly, mice were anesthetized with isoflurane, submerged in ice-cold oxygenated perfusate, decerebrated, and transected caudal to the diaphragm. The torso and brainstem were then transferred to a recording chamber, in which the descending aorta was cannulated with a double lumen cannula (one line to deliver perfusate, the second to monitor blood pressure) and perfused with saline [125 mM NaCl, $4 \mathrm{~mm} \mathrm{KCl,} 1.25 \mathrm{~mm} \mathrm{MgSO}_{4}, 24 \mathrm{~mm} \mathrm{NaHCO}$, $1.25 \mathrm{~mm} \mathrm{KH}_{2} \mathrm{PO}_{4}, 2.5 \mathrm{~mm} \mathrm{CaCl}_{2}, 10 \mathrm{~mm}$ D-glucose, and $1.3 \%$ Ficoll (Sigma) bubbled with $95 \% \mathrm{O}_{2}-5 \% \mathrm{CO}_{2}$ at a flow rate of $15-22 \mathrm{ml} / \mathrm{min}$ ] sufficient to generate and maintain arterial pressure at $60 \mathrm{mmHg}(<8$ min from initial submersion). Once perfusion was initiated and arterial pressure was stabilized, the preparation was gradually warmed to $30^{\circ} \mathrm{C}$ by heating the perfusate. The preparation was then allowed to stabilize for 
$1 \mathrm{~h}$, during which time the left phrenic nerve was dissected to monitor inspiratory activity (frequency and burst amplitude). After the $1 \mathrm{~h}$ stabilization period, baseline respiratory output was recorded. Respiratory rhythm in WHBP was monitored from the phrenic nerve, which was placed over two platinum hook electrodes. Signals were amplified, rectified, low-pass filtered, and recorded to a computer, using an analog-todigital converter (Molecular Devices Digidata 1200) and data acquisition (Axoscope) and analysis (Clampfit) software.

Data analyses. Data are expressed as mean \pm SEM. The coefficient of variation of breathing frequency was calculated by dividing the SD by arithmetic mean of breathing frequency. The respiratory parameters were measured over a period of at least $5 \mathrm{~min}$ for both in vivo and WHBP except for the chemoreceptive experiments in which we analyzed the reflex response to hypoxia and hypercapnia for $1 \mathrm{~min}$. For minute ventilation measurements, the values were reported as mean relative to WT control during quiet wakefulness. SigmaStat 3.5 (Systat Software) was used to perform statistical analyses. In intact animals and WHBP experiments, the significance of changes in the respiratory parameters, stress hormone corticosterone, fecal boli, and body weight were evaluated by a one-way ANOVA with Tukey's post hoc test (multiple groups) or $t$ test (two groups). Statistical comparisons of data were performed only after verification of normality. The analysis of survival rates was made with the Kaplan-Meier log-rank test. Correlation of respiratory phenotype against measures of corticosterone was examined by Spearman's rank order test, with a correlation coefficient close to 1 , and $p<0.001$ indicating a strong positive correlation. $p<0.05$ was taken to indicate a significant difference between means.

\section{Results \\ $M e c p 2^{-/ y}$ mice show progressive respiratory dysfunction in vivo}

We initiated the study by performing a longitudinal analysis of the respiratory pattern of individual mice. We observed that $M e c p 2^{-/ y}$ mice express two stages of respiratory dysfunction. Figure $1 A$ shows representative plethysmographic traces of WT mice during quiet wakefulness and sleep. The recording in Figure $1 A$ is from a postnatal day 32 (P32) WT mouse. Respiratory patterns were similar among WT animals of similar ages (P32-P115). Recordings from $M e c p 2^{-/ y}$ mice under similar conditions are shown in Figure $1 B$ (all recordings in a large $260 \mathrm{ml}$ chamber). In initial experiments, mice were instrumented for EEG recordings from the cerebral cortex and EMG from neck muscle in combination with whole-body plethysmographic recordings (Fig. $1 C$; $n=3$ each for WT and Mecp $2^{-/ y}$ mice) to verify that the subsequently used observational methods of demarcating sleep from wake state were reliable. All of the $M e c p 2^{-/ y}$ mice studied showed a markedly abnormal breathing pattern by $\sim 1-2$ months of age. At the early stage, $M e c p 2^{-/ y}$ mice had an unstable breathing pattern characterized by fast breathing interposed by decreased frequency of breathing and marked apneas during quiet wakefulness but not during sleep. Thus, in this study, we defined early stage of respiratory dysfunction as marked apneas during wakefulness but not during sleep. We did not analyze breathing patterns during gross body movements (i.e., walking or turning around within the chamber). Over time, $M e c p 2^{-/ y}$ mice began to display apneas during sleep as well as wakefulness. The onset and progress of respiratory dysfunction varied among the cohort of Mecp2 $2^{-/ y}$ mice examined. In the majority (9 of 13) of mice, the onset of apneas during wakefulness appeared at approximately P32. Sleep apneas started appearing $1-3$ weeks later and became more frequent and longer lasting with age (Fig. $1 D$ shows apneas before death). Two Mecp $2^{-1 y}$ mice (of 13 animals tested) had clear wakefulness apnea by P26, sleep apnea from day P34, and died at P43 and P45. The remaining two Mecp $2^{-/ y}$ studied had marked wakefulness apnea from
P46 to P50. All 13 Mecp $2^{-/ y}$ mice died at 6-12 weeks of age. The population data showing age-dependent differences between $M e c p 2^{-1 y}$ and WT mice in apneas per minute, respiratory frequency, coefficient of variation $(f)$, and relative minute ventilation are shown in Figure $1 E$. Because of the fact that the onset of the respiratory phenotype varied between individual mice, the population data for age-dependent changes in respiratory parameters are normalized, with day 0 defined as the day immediately before the onset of marked apnea during wakefulness.

\section{Altered chemoreceptive responses in $\mathrm{Mecp}^{-/ y}$ mice}

Chemoreceptive responses to altered levels of ambient $\mathrm{O}_{2}$ and $\mathrm{CO}_{2}$ were also examined via plethysmography. Note that our system allowed for rapid gas exchange (12 s), and we focused our measurements on the primary response $(1 \mathrm{~min}$ duration after allowing $12 \mathrm{~s}$ for equilibration of gases) to hypoxia and hypercapnia. Representative traces from WT and $M e c p 2^{-/ y}$ mice (during the early and late stages of respiratory dysfunction) in room air and after exposure to hypoxia $\left(8 \% \mathrm{O}_{2}\right)$ and hypercapnia $(5 \%$ $\mathrm{CO}_{2}$ ) are shown in Figure $2 \mathrm{~A}$ (during quiet wakefulness). Population data showing frequency (relative to room air) and coefficient of frequency variation are shown in Figure $2 B$. There was a trend for an increased breathing frequency and coefficient of variation in response to hypoxia and hypercapnia in $M e c p 2^{-1 y}$ $(n=5)$ relative to WT $(n=6)$ mice at early stages, but the differences were not statistically significant. However, by late stages of respiratory dysfunction, Mecp $2^{-/ y}$ mice had a significantly altered response to hypoxia $\left(8 \% \mathrm{O}_{2}, n=5\right)$, as evident by significantly increased relative frequency $\left(2.1 \pm 0.12, F_{(2,13)}=12\right.$, $p=0.001)$ and coefficient of variation of respiratory frequency $\left(0.33 \pm 0.04, F_{(2,13)}=4.7, p=0.02\right)$ compared with WT (relative frequency, $1.42 \pm 0.07$; coefficient of variation of respiratory frequency, $0.18 \pm 0.02)$. Similarly, Mecp $2^{-/ y}$ mice had a significantly altered response to hypercapnia $\left(5 \% \mathrm{CO}_{2}, n=5\right)$ as evident by significantly increased relative frequency $(1.84 \pm 0.15$, $\left.F_{(2,13)}=6.8, p=0.012\right)$ and coefficient of variation of respiratory frequency $\left(0.31 \pm 0.04, F_{(2,13)}=9.3, p=0.003\right)$ compared with WT (relative frequency, $1.35 \pm 0.08$; coefficient of variation of respiratory frequency, $0.14 \pm 0.02$ )

\section{CRHR1-mediated, heightened anxiety and stress in Mecp $2^{-/ y}$ mice}

Typically, the size of plethysmographic chambers is kept to a minimum when recording rodent respiratory patterns to maximize the signal-to-noise ratio. However, we noted that, compared with other mouse strains, many of the $M e c p 2^{-/ y}$ mice showed excessive hyperventilation, followed by apneas when placed in the confining $50 \mathrm{ml}$ chamber, suggesting heightened anxiety. This anxious, hyperventilatory-apneic behavior was markedly decreased when animals were placed in the larger 260 $\mathrm{ml}$ plethysmographic chamber. These observations in conjunction with past reports of heightened anxiety in $M e c p 2^{-/ y}$ and Mecp $2^{308 / y}$ mice (Gemelli et al., 2006; Fyffe et al., 2008; Adachi et al., 2009) led us to investigate further the stress response and how it relates to respiratory dysfunction in the mouse model. First, we measured stress-related behavior (fecal bolus) in WT and $M e c p 2^{-1 y}$ mice (early-stage respiratory phenotype) under the following conditions: basal conditions (in a large plethysmographic chamber); restraint stress (in a smaller plethysmographic chamber); stress induced by exposure to TMT in large chambers; and placement in large or small chambers $20 \mathrm{~min}$ after administration of the CRHR1 antagonist antalarmin $(10 \mathrm{mg} / \mathrm{kg}$, i.p.). Figure $3 \mathrm{~A}$ shows the number of fecal boli counted in the first $10 \mathrm{~min}$ after a 

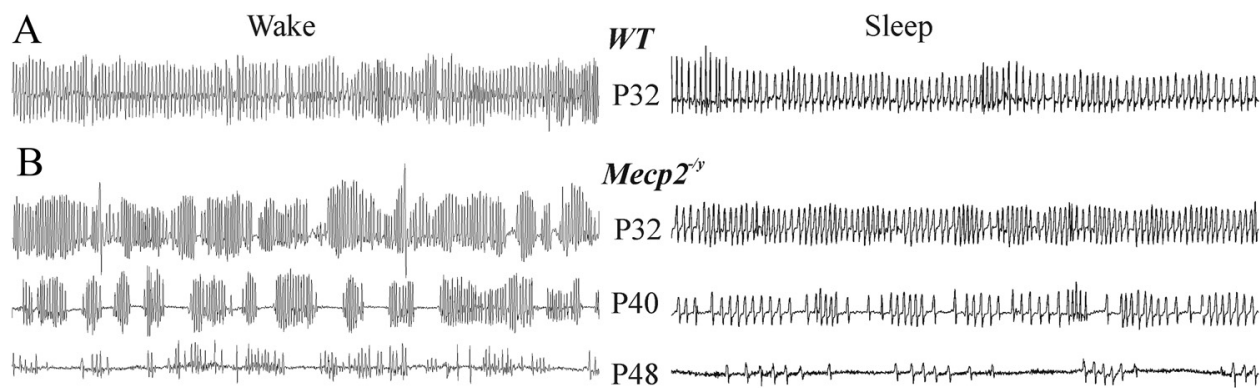

$\operatorname{Mecp} 2^{-1 y}$

C

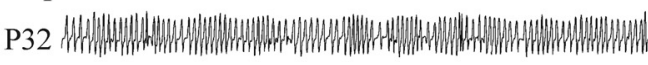

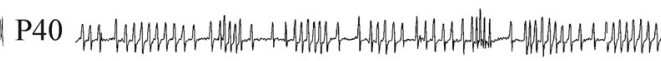

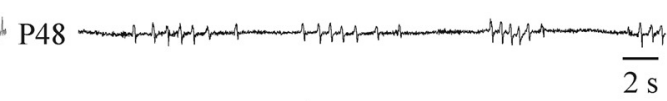

$M e c p 2^{-y}$ (early-stage)

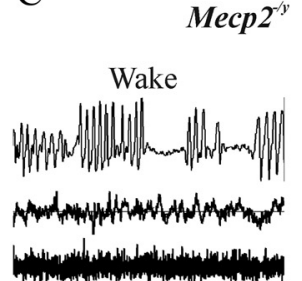

D
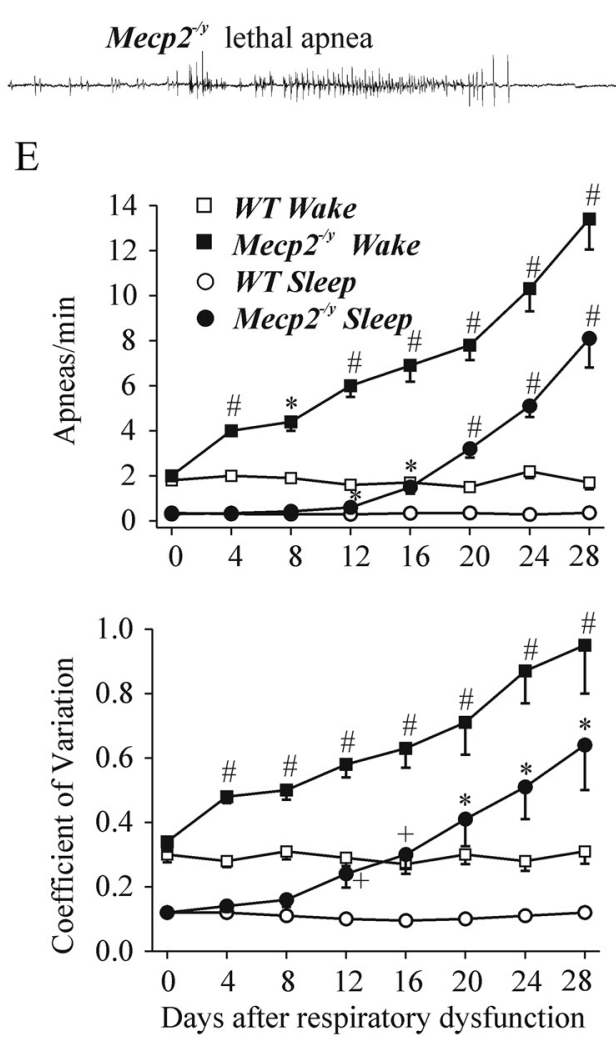

$\operatorname{Mecp2}^{-/ y}$ (late-stage)

Wake

Sleep

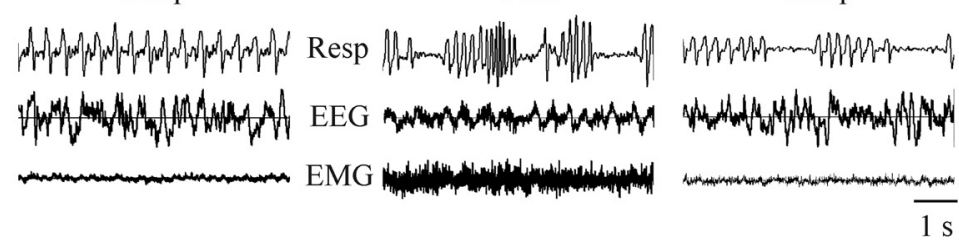

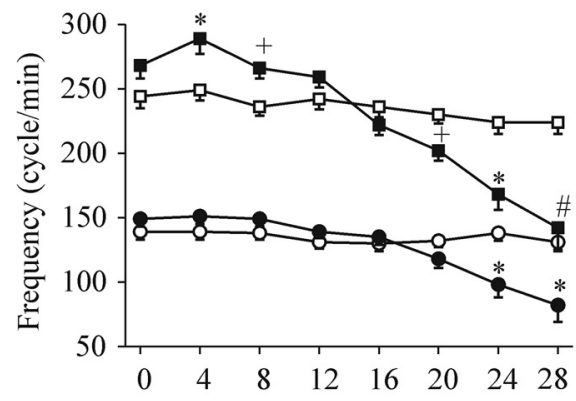

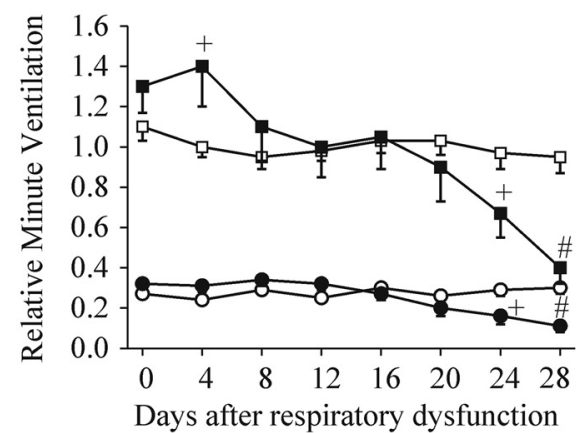

Figure 1. Age- and state-dependent changes in the respiratory patterns of WT and $M e c p 2^{-1 y}$ mice. Representative whole-body plethysmographic measurements of the respiratory activity of unrestrained WT $\left(\boldsymbol{A}\right.$, P32) and Mecp2 ${ }^{-1 y}$ (B, from one animal of different developmental ages P32, P40, and P48) mice during quiet wakefulness (left) and sleep (right). $\boldsymbol{C}$, Sleep-wake stage recordings showing plethysmographic traces (Resp), EEG, and neck EMG from Mecp2 ${ }^{-1 y}$ mice at early and late stages of disease progression. D, Plethysmographic recordings from an Mecp $2^{-1 y}$ mouse made during the final few minutes before terminal apnea. $\boldsymbol{E}$, Population data showing the number of apneas per minute, respiratory frequency, coefficient of variation of respiratory frequency, and minute ventilation (relative to WT control during quiet wakefulness) at different ages and wake-sleep states. $n=7-13$ for each data point; ${ }^{+} p<0.05,{ }^{*} p<0.01$, and ${ }^{\#} p<0.001$ compared with day 0 and between WT and Mecp $2^{-1 y}$ mice. Note that days plotted are normalized to start just before the onset of clear wakefulness apneas (the onset varied with age among the population of Mecp2 $2^{-1 y}$ mice studied; for details, see Results).

mouse was put in the chamber for plethysmographic recordings. $M e c p 2^{-1 y}$ mice $\left(4.4 \pm 0.53 / 10 \mathrm{~min}, n=7, t_{(12)}=3.4, p=0.006\right)$ deposited significantly more fecal boli than WT $(2.3 \pm 0.36 / 10$ $\min , n=7)$ in the large plethysmographic chamber. Within the smaller chamber, both WT $\left(4.2 \pm 0.6 / 10 \mathrm{~min}, n=6, F_{(3,21)}=6.5\right.$, $p=0.02)$ and $M e c p 2^{-/ y}\left(7.2 \pm 0.6 / 10 \mathrm{~min}, n=6, F_{(3,21)}=15, p=\right.$
0.005) mice significantly increased fecal boli deposition relative to the larger chamber. More fecal boli were observed in Mecp $2^{-/ y}$ relative to $\mathrm{WT}\left(t_{(10)}=3.5, p=0.005\right)$ mice in the small chamber. Exposure to the TMT odor induced a similar significant increase in fecal bolus deposition in WT $\left(4.0 \pm 0.37 / 10 \mathrm{~min}, n=6, F_{(3,21)}\right.$ $=6.5, p=0.037)$ and $M e c p 2^{-/ y}\left(6.2 \pm 0.48 / 10 \mathrm{~min}, n=6, t_{(11)}=\right.$ 
A

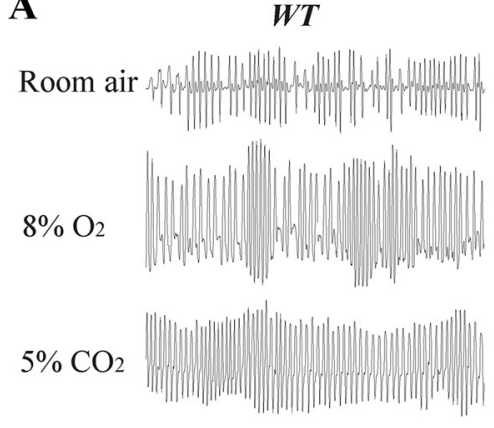

\section{B}

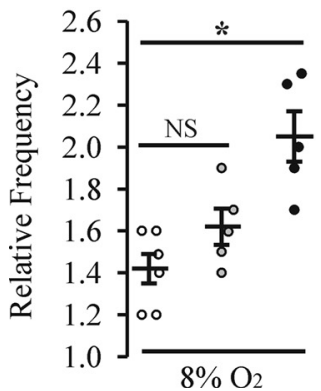

○WT
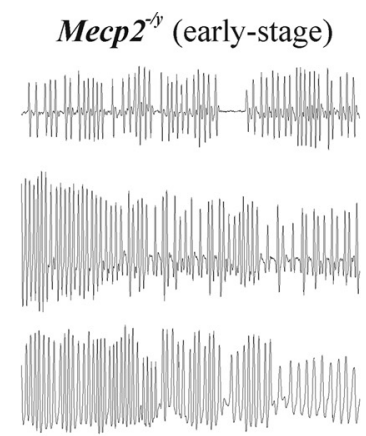
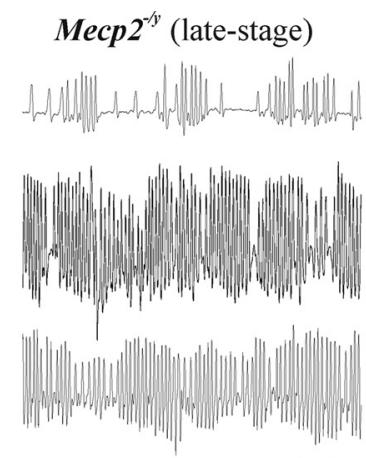

$\overline{1 s}$

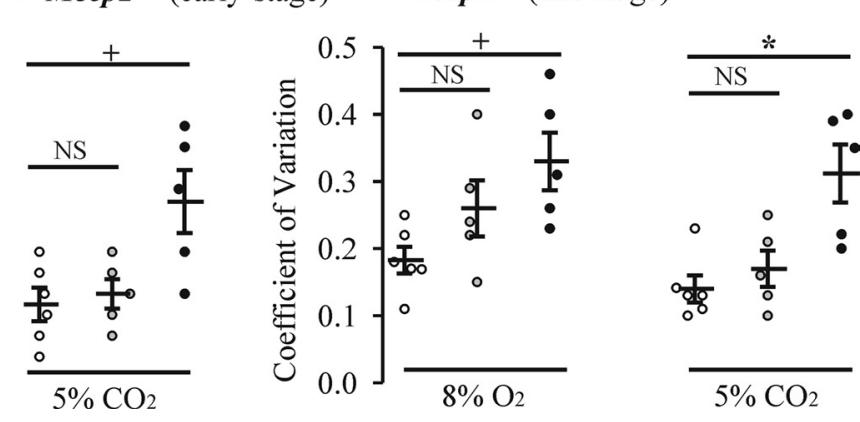

Figure 2. Ventilatory response to hypoxia and hypercapnia. $A$, Representative whole-body plethysmographic measurements of breathing from a P52 WT, a P40 Mecp2 $2^{-1 y}$ (with an early-stage of respiratory dysfunction), and a $\mathrm{P} 52 \mathrm{Mecp} 2^{-1 / y}$ (with a late-stage of respiratory dysfunction) mouse in room air, hypoxia $\left(8 \% \mathrm{O}_{2}\right)$, or hypercapnia $\left(5 \% \mathrm{CO}_{2}\right) \cdot \boldsymbol{B}$, Population data showing the responses of WT $(n=6)$, early-stage $(n=5)$, and late-stage $(n=5)$ Mecp $2^{-1 y}$ mice to hypoxia and hypercapnia; frequency (relative to room air) and the coefficient of variation of respiratory frequency are plotted. Relative frequency (frequency in room air delineated as 1 ) was compared because the baseline respiratory frequency was slow in room air in the late-stage Mecp $2^{-1 /}$ mice. ${ }^{\text {NS }} p \geq 0.05,{ }^{+} p<0.05,{ }^{*} p<0.01$ and between two groups.

2.4, $p=0.035)$ mice as the smaller chamber, with the effect on $M e c p 2^{-/ y}$ mice being significantly greater than in WT mice $\left(t_{(10)}\right.$ $=3.6, p=0.005)$. In the final paradigm, WT and $M e c p 2^{-1 y}$ were administered antalarmin $(10 \mathrm{mg} / \mathrm{kg}$, i.p.) before being placed in the large plethysmographic chamber $(n=3)$ or small chamber $(n=3)$. This had no effect on fecal boli deposition in WT mice in large chamber but decreased the fecal boli in small chamber $\left(t_{(7)}\right.$ $=2.4, p=0.049)$. However, antalarmin pretreatment decreased the fecal boli deposition by Mecp $2^{-/ y}$ mice in both large and small chambers to a level $(2.5 \pm 0.43 / 10 \mathrm{~min}, n=6)$ comparable with WT mice in large chambers. Antalarmin data from large and small chambers were pooled together in counts of fecal boli because they were not significantly different.

The experimental protocols were repeated and the stressrelated hormone corticosterone in blood samples isolated from $M e c p 2^{-/ y}$ and WT mice was measured $1 \mathrm{~h}$ after removing the animal from the plethysmograph chamber (population data shown in Fig. 3B). Note that corticosterone data from animals placed in their home cage were pooled with data from animals placed in the large chamber (Fig. 3B, large) because there was no significant difference between them. These data (home cage and large chamber) pooled for the WT animals were used as the reference point ( $78 \pm 10 \mathrm{ng} / \mathrm{ml}, n=6$ ) for all other experimental groups. The corticosterone levels of $M e c p 2^{-/ y}$ mice taken from their home cages $(n=3)$ or after spending $1 \mathrm{~h}$ in the large plethysmographic chamber $(n=3)$ were significantly elevated $\left(122 \pm 12 \mathrm{ng} / \mathrm{ml}, t_{(10)}=2.9, p=0.017\right)$ relative to similarly treated WT mice. Corticosterone levels increased significantly in response to restraint stress in the small plethysmographic chamber $\left(119 \pm 11 \mathrm{ng} / \mathrm{ml}, n=6, F_{(3,19)}=6.4, p=0.046\right)$ or to TMT exposure $\left(131 \pm 11 \mathrm{ng} / \mathrm{ml}, n=5, F_{(3,19)}=6.4, p=0.012\right)$ in WT. Similarly, corticosterone levels increased significantly in response to restraint stress in the small plethysmographic chamber (176 \pm $\left.19 \mathrm{ng} / \mathrm{ml}, n=6, t_{(10)}=2.5, p=0.032\right)$ or to TMT exposure $\left(208 \pm 16 \mathrm{ng} / \mathrm{ml}, n=5, F_{(3,19)}=14, p=0.004\right)$ in $M e c p 2^{-l y}$ mice. The increase in the mutant mice was significantly greater than in WT mice in both the small $\left(t_{(10)}=2.7, p=0.023\right)$ or large $\left(t_{(8)}=\right.$ $4, p=0.004)$ chambers when exposed to TMT. Twenty minutes after administration of antalarmin, WT and $M e c p 2^{-/ y}$ mice were placed in the large $(n=3)$ or small $(n=3)$ chamber for $1 \mathrm{~h}$. This had no effect on blood corticosterone levels in WT mice in the large chamber but decreased the corticosterone concentration when placed in the small chamber $\left(t_{(7)}=2.4, p=0.049\right)$. However, antalarmin pretreatment decreased the corticosterone level in $M e c p 2^{-/ y}$ mice in both large and small chambers to a level $(84 \pm 12 \mathrm{ng} / \mathrm{ml}, n=6)$ comparable with WT mice in large chambers. Corticosterone data from animals placed in large and small chambers after antalarmin were pooled because they were not significantly different.

\section{Stress-related respiratory dysfunction in $M e c p 2^{-/ y}$ mice in vivo}

To correlate the respiratory phenotype with the analyses of stressrelated responses, we performed plethysmographic recordings from $M e c p 2^{-l y}$ and WT mice under basal conditions (in the large chamber), with restraint stress (in the small chamber), after exposure to TMT $(0.5 \mu \mathrm{l})$, and when animals were placed in large or small chambers after administration of the CRHR1 antagonist antalarmin $(10 \mathrm{mg} / \mathrm{kg}$, i.p.). As shown in representative plethysmographic recordings in Figure $4 A, M e c p 2^{-/ y}$ mice with the early-stage respiratory phenotype had an unstable breathing pattern during wakefulness in the large plethysmographic chamber ( $n=6$; apneas, $4.2 \pm 0.4 / \mathrm{min}, t_{(10)}=5.1, p<0.001$; coefficient of frequency variation, $\left.0.44 \pm 0.04, t_{(10)}=3.4, p=0.007\right) \mathrm{com}-$ 

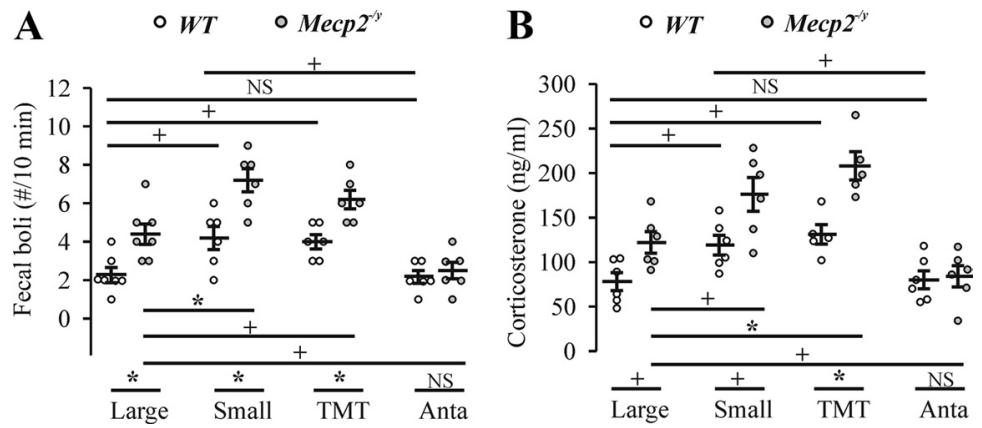

Figure 3. Stress as measured by fecal boli deposition and corticosterone levels in WT and Mecp $2^{-1 / y}$ mice (early stage). $\boldsymbol{A}$, Number of fecal boli deposited within the first 10 min after mice were placed in large ( $n=7$ each for WT and Mecp $2^{-1 y}$ groups) or small ( $n=6$ each for WT and Mecp $2^{-1 y}$ groups) plethysmographic chambers, exposed to TMT ( $0.5 \mu \mathrm{l} ; n=6$ each for WT and Mecp $2^{-1 y}$ groups) or administered antalarmin before placement in large or small chambers $(10 \mathrm{mg} / \mathrm{kg}$, i.p., $n=6$ each for WT and Mecp2 ${ }^{-1 y}$ groups; among them, $n=3$ each for large and small chamber). $\boldsymbol{B}$, Blood corticosterone levels after mice were taken from their home cages ( $n=3$ each for WT and Mecp $2^{-/ y}$ groups), after $1 \mathrm{~h}$ in large ( $n=3$ each for WT and Mecp $2^{-/ y}$ groups) or small ( $n=6$ each for WT and Mecp $2^{-1 y}$ groups) plethysmographic chambers, exposed to TMT ( $0.5 \mu l, n=5$ each for WT and Mecp2 $2^{-1 y}$ groups) or administered antalarmin before placement in a chamber $\left(10 \mathrm{mg} / \mathrm{kg}\right.$, i.p., $n=6$ each for WT and Mecp2 $2^{-1 y}$ groups; among them, $n=3$ each for large and small chamber). ${ }^{\mathrm{NS}} p \geq 0.05,{ }^{+} p<0.05$, and ${ }^{*} p<0.01$ between two groups.

pared with WT $(n=6$, apnea, $1.8 \pm 0.26 / \mathrm{min}$; coefficient of frequency variation, $0.27 \pm 0.03$ ). Even WT had irregular breathing pattern when placed in the small plethysmographic chamber $\left(n=6\right.$; apnea, $3.9 \pm 0.38 / \mathrm{min}, F_{(3,19)}=7.2, p=0.004$; coefficient of frequency variation, $\left.0.41 \pm 0.04, t_{(10)}=3.1, p=0.011\right)$ or when exposed to TMT ( $n=5$; apnea, $3.5 \pm 0.47 / \mathrm{min}, F_{(3,19)}=$ $7.2, p=0.027$; coefficient of frequency variation, $0.43 \pm 0.05$, $\left.F_{(3,19)}=5.3, p=0.04\right)$. Similarly, these breathing pattern irregularities were accentuated when placed in the small plethysmographic chamber $\left(n=6\right.$; apnea, $7.8 \pm 0.87 / \mathrm{min}, F_{(3,19)}=12.5$, $p=0.018$; coefficient of frequency variation, $0.64 \pm 0.05, F_{(3,19)}$ $=11, p=0.048)$ or when exposed to TMT $(n=5$; apnea, $7.7 \pm$ $1.15 / \mathrm{min}, F_{(3,19)}=12.5, p=0.019$; coefficient of frequency variation, $\left.0.68 \pm 0.06, F_{(3,19)}=11, p=0.016\right)$ in Mecp $2^{-1 y}$ mice. The increase in these breathing pattern irregularities in mutant mice was significantly greater than in WT mice in both small $\left(t_{(10)}=\right.$ 3.9, $p=0.003)$ and large $\left(t_{(8)}=3.4, p=0.009\right)$ chamber after exposure to TMT. Note that these data have implications for interpreting the degree of respiratory abnormalities in plethysmographic studies of RTT mouse models because the severity of the respiratory pattern disturbance will relate to amount of stress associated with the measurement apparatus. Administration of antalarmin to WT increased the regularity of respiratory pattern in the small chamber (apnea, $2.2 \pm 0.42 / \mathrm{min}, F_{(3,19)}=7.2, p=$ 0.021 ; coefficient of frequency variation, $0.27 \pm 0.04, t_{(10)}=2.8$, $p=0.019)$, without a significant difference in the large chamber. Administration of antalarmin to Mecp $2^{-l y}$ increased the regularity of respiratory pattern $\left(n=6\right.$; apnea, $2.4 \pm 0.45 / \mathrm{min}, F_{(3,19)}=12.5$, $p<0.001$ compared with the small chamber; $t_{(10)}=3, p=0.014$ compared with big chamber; coefficient of frequency variation, $0.34 \pm 0.04, F_{(3,19)}=11, p=0.002$ compared with small chamber). After antalarmin, there is no significant difference in the regularity of respiratory pattern (apnea, $t_{(10)}=0.4, p=0.69$; coefficient of frequency variation, $t_{(10)}=1.2, p=0.25$ ) between WT and $M e c p 2^{-1 y}$. Population data are shown in Figure $4 B$ for the number of apneas and coefficient of variation of frequency of $M e c p 2^{-1 y}$ mice during early-stage disease under the various experimental conditions. We then plot the severity of the respiratory phenotype (i.e., apneas per minute and coefficient of variation of frequency) against the measure of stress (blood corticosterone level) in Mecp $2^{-/ y}$ mice during early-stage disease as measured under the various stressinducing experimental conditions $(n=$ $20)$. The correlation coefficients were 0.87 and 0.83 for apneas per minute and the coefficient of variation of respiratory frequency, respectively (Fig. $4 C ; p<0.001$ ). All data demonstrate that respiratory abnormalities correlate with the level of stress (as indicated by blood corticosterone levels).

Figure $5 A$ shows the irregular breathing pattern of a Mecp $2^{-/ y}$ mouse at later stages when there were clear apneas during sleep. Figure $5 B$ shows population data for the number of apneas and coefficient of variability during quiet wakefulness and sleep in $M e c p 2^{-/ y}$ mice with late-stage respiratory phenotype. Administration of antalarmin (10 mg/kg, i.p., $n=5$ ) partially decreased the number of apneas $\left(F_{(2,16)}=22, p=\right.$ $0.007)$ and the irregularity of breathing $\left(F_{(2,16)}=18, p=0.024\right)$ during wakefulness in $M e c p 2^{-/ y}$ mice. In the presence of antalarmin, Mecp $2^{-/ y}$ mice $(n=5)$ still had an irregular respiratory pattern (apnea, $3.9 \pm 0.88$ / $\min , F_{(2,16)}=22, p=0.048$; coefficient of frequency variation, $\left.0.45 \pm 0.07, F_{(2,16)}=18, p=0.047\right)$ compared with WT $(n=9$; apnea, $1.7 \pm 0.21 / \mathrm{min}$; coefficient of frequency variation, $0.27 \pm$ 0.023 ) mice during wakefulness. Furthermore, administration of antalarmin did not significantly decrease the number of apneas $\left(F_{(2,16)}=16, p=0.86\right)$ and the irregularity of breathing $\left(F_{(2,16)}=13\right.$, $p=0.44)$ during sleep in $M e c p 2^{-y}$ mice $(n=5)$.

We next tested whether chronic antalarmin treatment (single daily intraperitoneal injection of $10 \mathrm{mg} / \mathrm{kg}$ ) for $20 \mathrm{~d}$ (starting at P32) could prolong the life of Mecp $2^{-/ y}$ mice. As shown in Figure $6 A$, there was a modest but significant increase $(p=0.018, \mathrm{Ka}$ plan-Meier log-rank test) in the lifespan of the antalarmintreated Mecp $2^{-/ y}$ group to P75 $\pm \mathrm{P} 4(n=13)$ from $\mathrm{P} 63 \pm \mathrm{P} 2$ $(n=25)$ in the untreated/vehicle-treated group. Antalarmin treatment had no significant effect on the weight loss that occurs with age in $M e c p 2^{-/ y}$ mice (Fig. 6B).

\section{$M e c p 2^{-/ y}$ mice show progressive respiratory dysfunction in situ}

Based on our observations that respiration was normal during sleep and that there was a clear correlation between the degree of respiratory instability and behavioral state (e.g., stress levels) in the early-stage Mecp $2^{-/ y}$ mice, we hypothesized that the respiratory dysfunction of $M e c p 2^{-/ y}$ mice that occurs during the early stage of disease progression was not caused by an inherent problem with respiratory rhythmogenesis. To test this hypothesis, we examined the respiratory pattern generated by the reduced WHBP. The preparation generates a robust respiratory pattern without the influence of behavioral and state-dependent inputs from suprapontine brain structures. As shown in Figure 7, $A$ and $B$, WHBPs from WT $(n=5)$ and early-stage Mecp $2^{-/ y}$ mice $(n=$ 4) generated regular respiratory patterns as recorded from the phrenic nerve. There was no difference $\left(F_{(3,13)}=7.3, p=0.89\right)$ in the number of apneas in $M e c p 2^{-/ y}(0.96 \pm 0.22 / \mathrm{min})$ and WT $(0.67 \pm 0.16 / \mathrm{min})$ mice. In contrast, there were more central apneas $\left(F_{(3,13)}=7.3, p=0.007\right.$ compared with WT, $p=0.039$ compared with early stage of Mecp $\left.2^{-1 y}\right)$ in WHBPs isolated from later-stage $M e c p 2^{-1 y}$ mice $(2.2 \pm 0.38 / \mathrm{min}, n=5)$, in which apneas occurred during both wakefulness and sleep in intact an- 
A $\quad \operatorname{Mecp}^{2-y}$ (Wake, early-stage)
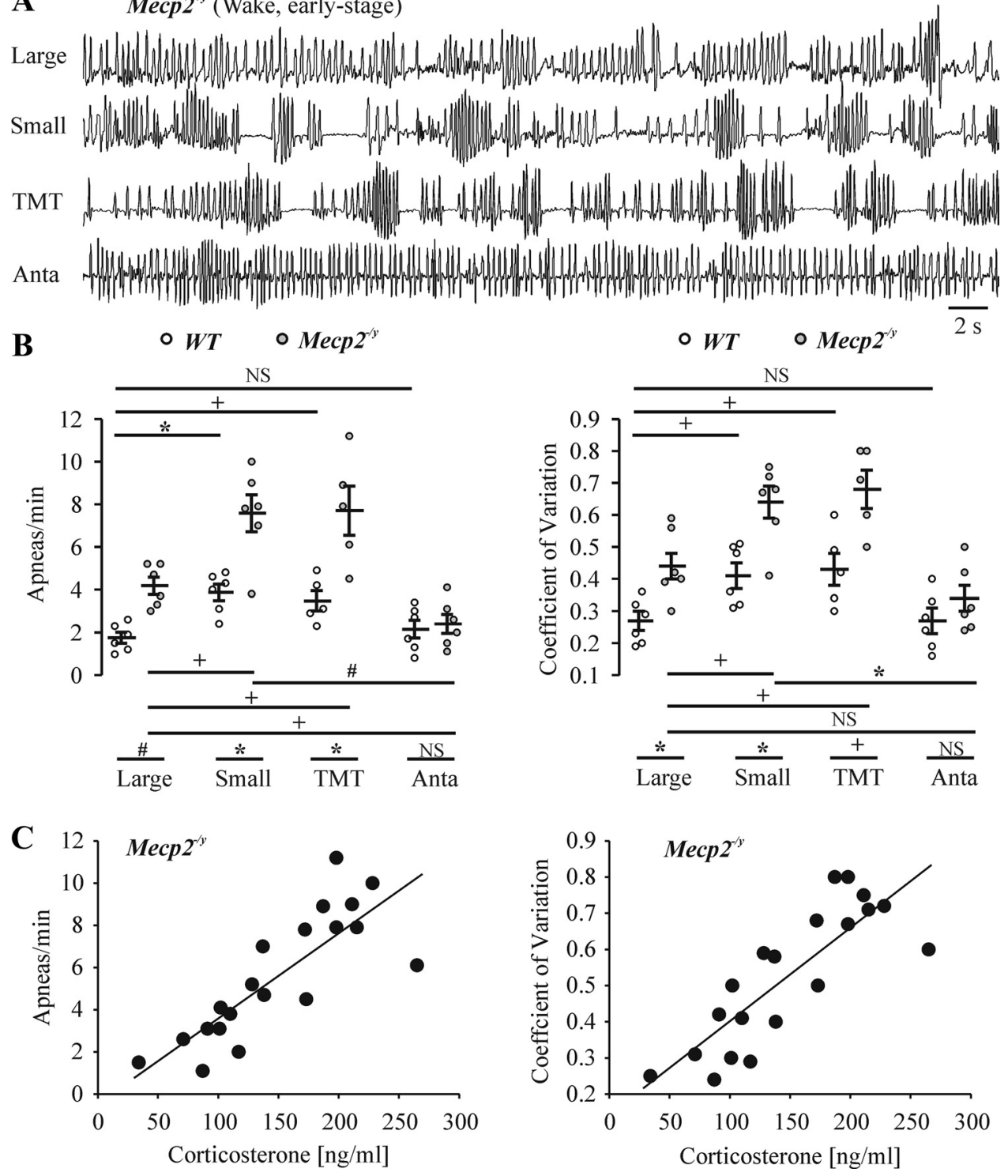

Figure 4. Respiratory patterns of WT and early-stage Mecp $2^{-1 y}$ mice in response to stress. $A$, Representative whole-body plethysmographic recordings of $M e c p 2^{-1 y}$ mice during wakefulness at early stage in the large chamber, the small chamber, during exposure to TMT ( $0.5 \mu$ l, in the large chamber), or treatment with antalarmin (Anta; $10 \mathrm{mg} / \mathrm{kg}$, i.p., in the small chamber at $40 \mathrm{~min}$ after drug administration). $\boldsymbol{B}$, Population data showing apneas per minute and coefficient of variation of frequency for WT and early-stage Mecp ${ }^{-1 y}$ mice during quiet wakefulness in large $(n=6$ each) and small ( $n=6$ each) plethysmographic chambers, exposure to TMT (in the large chamber, $n=5$ each) or administration of antalarmin before placement in the large ( $n=3$ each) or small chamber ( $n=3$ each). ${ }^{\mathrm{NS}} p \geq 0.05,{ }^{+} p<0.05$, and ${ }^{*} p<0.01$ between two groups. C, Correlation between the severity of respiratory dysfunction (apneas minute, coefficient of variation of frequency) and measures of stress (blood corticosterone level) in Mecp $2^{-1 y}$ mice. Data from large chamber $(n=3)$, small chamber $(n=6)$, TMT exposure (in large chamber, $\left.n=5\right)$, and antalarmin treatment (in large and small chamber, $n=3$ each) pooled together for analysis. Correlation coefficient was 0.87 and 0.83 for apneas per minute and coefficient of variation of respiratory frequency against blood corticosterone level, respectively, with $p<0.001$.

imals (Fig. 7C). The defects in central rhythmic activity in the WHBP were not affected by administration of antalarmin $(1 \mathrm{mg} /$ $100 \mathrm{ml}, n=3$; apnea, $\left.2.0 \pm 0.29 / \mathrm{min}, F_{(3,13)}=7.3, p=0.99\right)$. (Fig. 7D). Population data are shown in Figure $7 E$.

\section{Discussion}

This longitudinal study of Mecp $2^{-l y}$ mice characterized disease progression in relation to respiratory behavior and demonstrated two general stages. In the early stage, abnormalities in respiratory pattern were limited to wakefulness, exacerbated by stressful stimuli, and alleviated by the CRHR1 antagonist antalarmin, as well as the removal of descending suprapontine inputs to brainstem respiratory networks. In the later stage, respiratory abnor- malities were more severe, no longer state dependent, and manifest at the level of brainstem networks.

\section{Early stage}

Consistent with previous studies, the respiratory phenotype of Mecp $2^{-/ y}$ mice features a marked breathing dysfunction by 1-2 months of age (Viemari et al., 2005; Ogier et al., 2007; Stettner et al., 2007). Central apneas occur initially only during wakefulness. Data from the WHBP were consistent with normal output from brainstem respiratory networks in the absence of suprapontine structures. There was a clear correlation between respiratory phenotype and the level of anxiety. Even under baseline conditions, 
A $\quad \operatorname{Mecp}^{-/ y}$ (Sleep, late-stage)
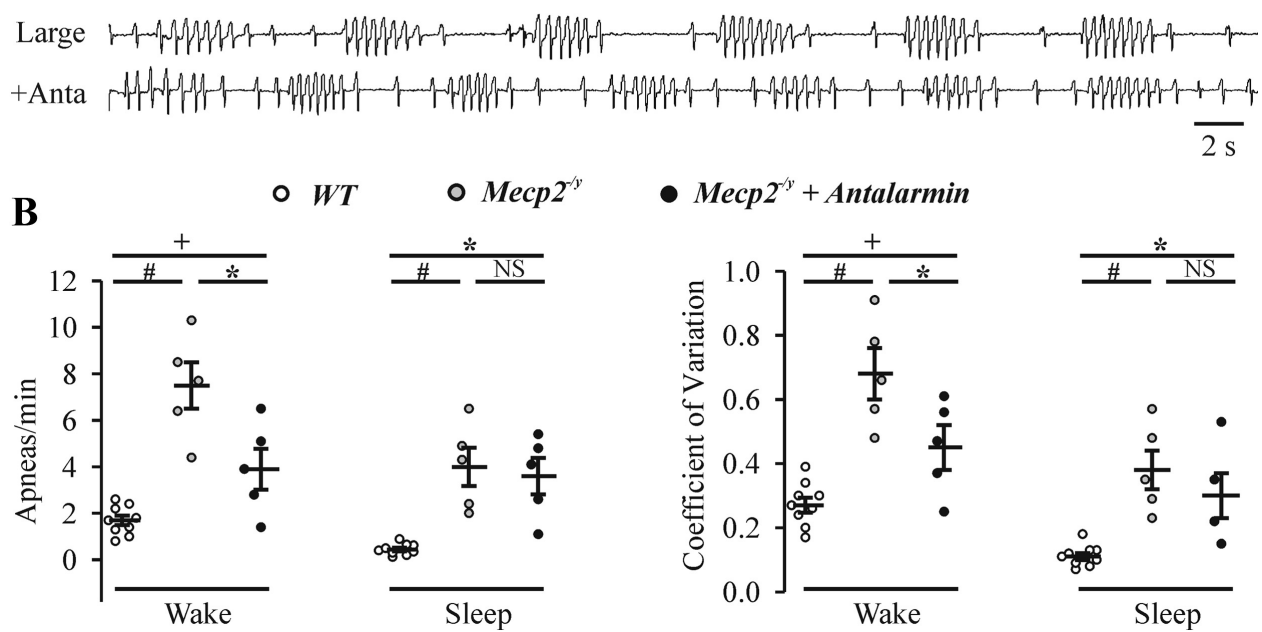

- Mecp2 $2^{-y}+$ Antalarmin

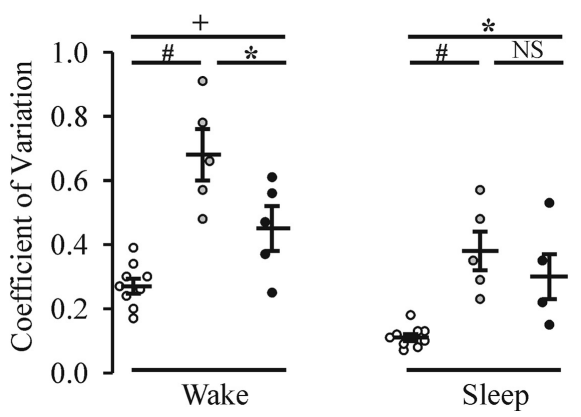

Figure 5. Respiratory patterns of late-stage Mecp $2^{-1 y}$ mice in response to treatment of CRHR1 blocker antalarmin. $A$, Representative whole-body plethysmographic recordings of $M e c p 2^{-1 y}$ mice during sleep at late stage in a large chamber under control conditions and $40 \mathrm{~min}$ after administration of antalarmin (Anta; $10 \mathrm{mg} / \mathrm{kg}$ i.p.). B, Population data showing apneas per minute and coefficient of variation for Mecp $2^{-1 y}$ mice during quiet wakefulness and sleep at late stage in large plethysmographic chambers with or without antalarmin pretreatment. $n=9$ for WT, $n=5$ for Mecp $2^{-1 y} ;{ }^{N S} p \geq 0.05,{ }^{+} p<0.05,{ }^{*} p<0.01$, and ${ }^{\#} p<0.001$ between two groups.

A

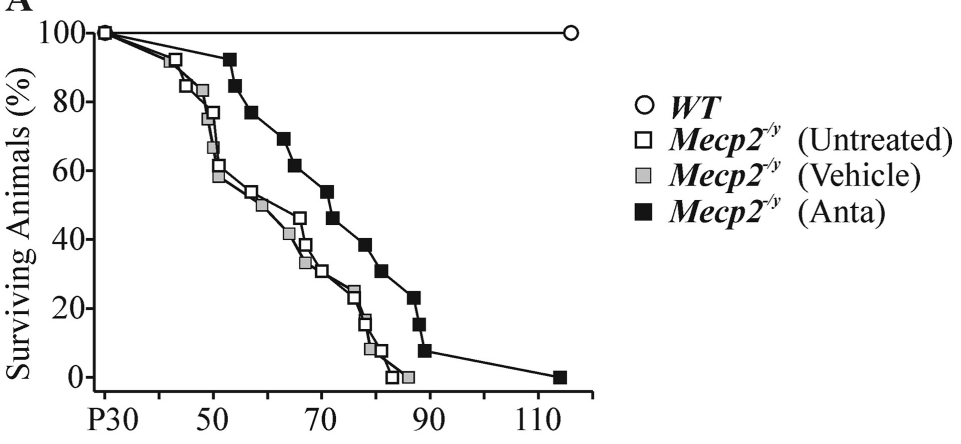

B
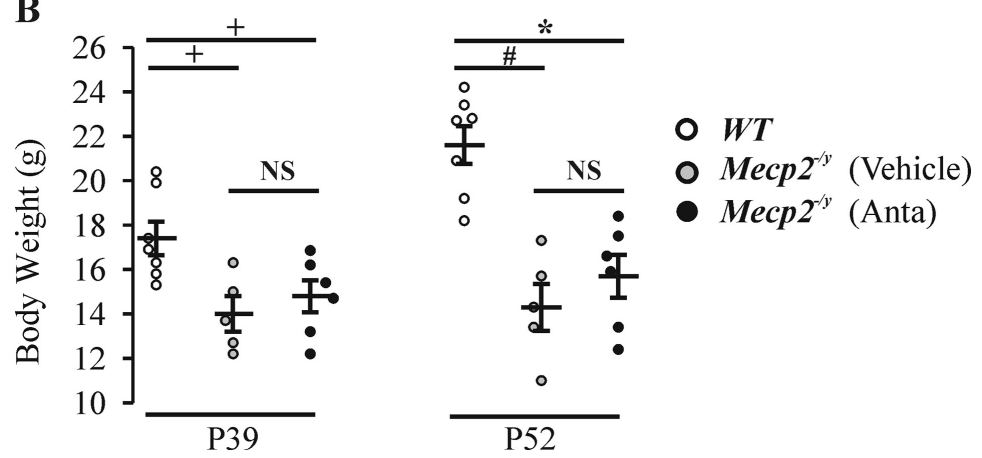

Figure 6. Effects of antalarmin treatment on lifespan and weight gain in WT and $M e c p 2^{-1 y}$ mice. $A$, Percentage of surviving WT and $M e c p 2^{-1 y}$ mice with age after treatment with vehicle (5\% DMSO in saline) and antalarmin (10 mg/kg, i.p., daily starting at P32). $\boldsymbol{B}$, Body weight of WT $(n=7)$, Mecp $2^{-1 y}$ mice at P39 and P52 after treatment with vehicle $(n=5)$ and after treatment of antalarmin $(n=6)$. ${ }^{\mathrm{NS}} p \geq 0.05,{ }^{+} p<0.05,{ }^{*} p<0.01$, and ${ }^{\#} p<0.001$ between two groups.

$M e c p 2^{-/ y}$ mice had elevated corticosterone levels and stressrelated behavior relative to WT mice. The differences were accentuated with the additional stressors of confinement or exposure to a threatening predator-related odor. Involvement in CRHR1 signaling was evident by the reduction of corticosterone release, stress-related behavior, and respiratory phenotype with administration of antalarmin. These data are consistent with previous reports of heightened anxiety in RTT mouse models (Gemelli et al., 2006; Fyffe et al., 2008; Adachi et al., 2009). Inputs from the amygdala, an origin of major $\mathrm{CRH}$-containing pathways to the brainstem and hypothalamus, and the bed nucleus of the stria terminalis are candidates for providing stress-related modulation of respiration (Swanson et al., 1983; Sakanaka et al., 1986; Gray and Bingaman, 1996; Pitkänen et al., 1997; Chen et al., 2000). This is supported by the markedly enhanced stress levels in mice with targeted Mecp2 deletions within those regions (Fyffe et al., 2008; Adachi et al., 2009).

Similar to antalarmin, several pharmacological interventions reduce respiratory phenotype of RTT mouse models. These include the norepinephrine transporter inhibitor desipramine (Roux et al., 2007; Zanella et al., 2008), benzodiazepines midazolam and diazepam (Voituron and Hilaire, 2011; Abdala et al., 2010), 5-HT receptor antagonist 8-OH-DPAT [8-hydroxy-2(di- $n$ propylamino)tetralin], GABA uptake inhibitorNO-711(1-[2([(diphenylmethylene) imino] oxy)ethyl]-1,2,5,6-tetrahydro-3-

pyridinecarboxylic acid hydrochloride), and the positive modulator of GABA receptor function, L-838,417 [3-(2,5-difluorophenyl)7-(1,1-dimethylethyl)-6-[(1-methyl-1 H-1,2, 4,-triazol-5-yl)methoxy]-1,2,4-triazolo[4,3-b ]pyridazine] (Abdala et al., 2010). It is noteworthy that these agents also have sedative, hypnotic, and/or anxiolytic properties (Brady et al., 1991; De Vry et al., 1993; Dalvi and Rodgers, 1996; Centeno and Volosin, 1997; Rudolph et al., 1999; Santibañez et al., 2006). Thus, it is likely a combination of anxiolytic effects and specific targeting of abnormal neurotransmitter signaling at respiratory nuclei that account for the beneficial effects. 


\section{Late stage}

As the disease progressed, apneas occurred during sleep and wakefulness. There was also a significant increase in inspiratory frequency and instability of breathing pattern in the presence of hypoxia and hypercapnia. Administration of antalarmin did not alleviate the apneas occurring during sleep. Recordings from the WHBP demonstrated that the apneas originated at the brainstem level and did not depend on disruptive modulatory input from suprapontine structures. These data are consistent with observations by Ward et al., (2011) who selectively deleted and restored Mecp 2 expression in mouse brainstem neurons. The baseline hyperventilation of their RTT model was dependent on input from supramedullary inputs, but the abnormal response to hypoxia and profound disturbances of autonomic control at latestage disease required brainstem Mecp2 deletion.

Stettner et al. (2007) reported central apneas in conjunction with abnormalities of the post-inspiratory vagal nerve discharge in WHBPs isolated from 40-d-old $M e c p 2^{-/ y}$ mice (Guy et al., 2001). This stage corresponds with the late stage of respiratory phenotype in the $M e c p 2^{-/ y}$ RTT model and is consistent with the late emergence of a central defect in rhythmogenesis. However, there is a report claiming a central defect in juvenile Mecp $2^{-/ y}$ mice well before any signs of apneas or irregular breathing (Viemari et al., 2005). This interpretation is based on recordings of thick medullary slice preparations with undefined rostrocaudal boundaries isolated from P14-P21 Mecp2 $2^{-/ y}$ mice that generate rhythmic bursting in vitro. In vivo, none of the mice from which the medullary slices were isolated demonstrated a respiratory phenotype. Also, there were no statistically significant differences in the number of apneas, frequency, amplitude, or duration of rhythmic motor bursting between $M e c p 2^{-/ y}$ and $\mathrm{WT}$ in vitro preparations. The only significant difference reported was a greater variability of inspiratory frequency in $M e c p 2^{-/ y}$ slices, which was interpreted as suggesting an early onset respiratory instability.

We propose that a number of factors working in concert with the abnormal stress-related network contribute to the late-stage respiratory phenotype in the mouse model. There are progressive perturbations of multiple neurotransmitter systems in RTT patients and mouse models, including acetylcholine, dopamine, serotonin, glutamate, GABA, and substance $\mathrm{P}$, all of which regulate respiratory rhythmogenesis (for review, see Katz et al., 2009; Roux and Villard, 2010). Surprisingly, deletion of Mecp2 from the majority of a specific class of aminergic neurons does not produce

E
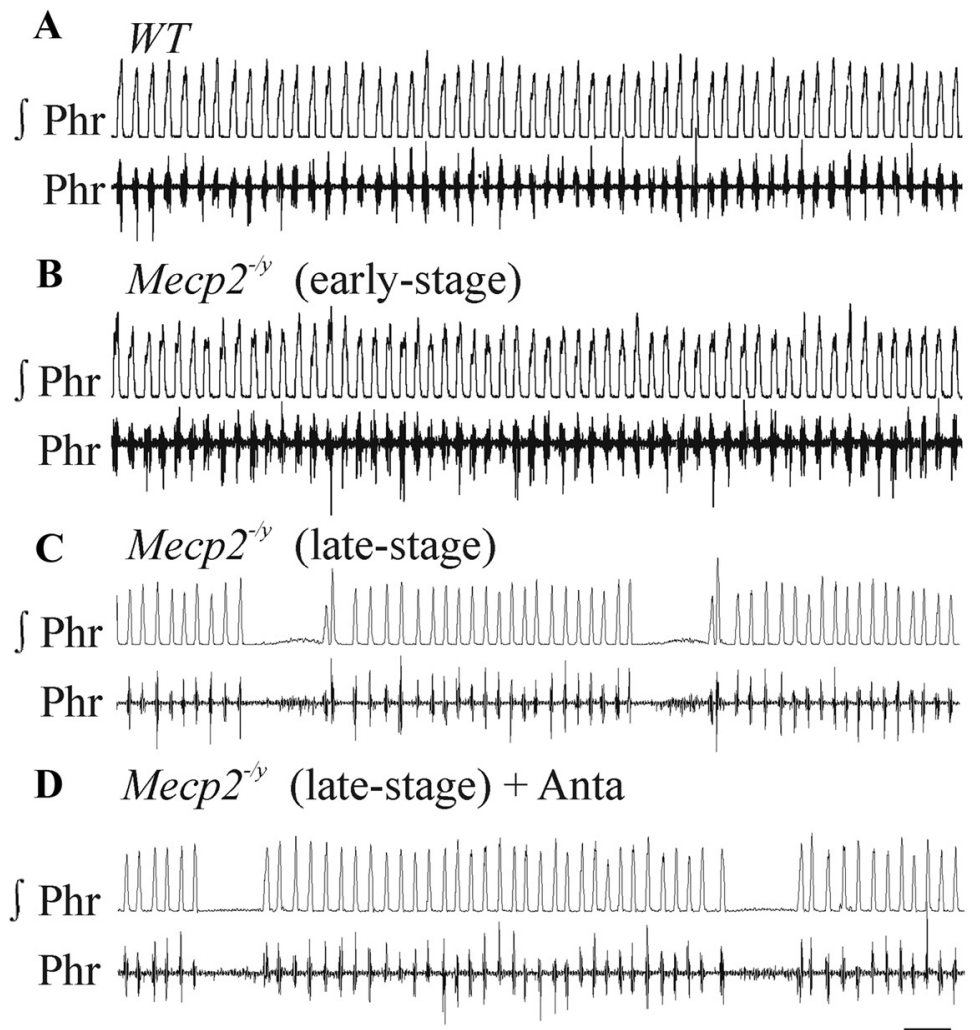

$2 \mathrm{~s}$

Figure 7. Respiratory rhythm generated by perfused in situ WHBPs of WT and Mecp2-1y mice at early and late stages. Integrated $\left(\int\right)$ and raw phrenic (Phr) nerve recordings from a P59 WT male $\left(\right.$ Mecp2 $\left.^{+/ y}\right)(\boldsymbol{A})$, P36 Mecp2 $^{-1 y}$ (early-stage) $(\boldsymbol{B})$, P44 Mecp $2^{-1 y}$ (late stage) $(\boldsymbol{C})$, and same WHBP preparation (D) from after application of CRHR1 antagonist antalarmin $(1 \mathrm{mg} / 100 \mathrm{ml})$ (C) .E, Population data showing the numbers of apneas per minute. $n=5,4,5$, and 3 for WT, early-stage Mecp $2^{-1 y}$, later-stage Mecp $2^{-1 y}$ before antalarmin, and later-stage Mecp $2^{-/ y}$ in the presence of antalarmin, respectively. ${ }^{\mathrm{NS}} p \geq 0.05,{ }^{+} p<0.05$, and ${ }^{*} p<0.01$ between the two groups.

a profound respiratory phenotype or early lethality (Samaco et al., 2008), as proposed from previous studies (Viemari et al., 2005). More likely, the respiratory phenotype results from a combination of multiple neuromodulatory deficits and a wide range of structural and functional changes at multiple levels of brain organization (for review, see Neul and Zoghbi, 2004; Chahrour and Zoghbi, 2007; Weng et al., 2011). This includes reduced brain size and weight and changes in neuronal density and morphology, including reduced dendritic branching, axonal fasciculation, 
and changes in spine density and morphology. Functionally, there are alterations in neuronal firing properties, synaptic signaling, frequency, and amplitude of synaptic events and basal inhibitory and excitatory synaptic transmission. Deficits in the expression of brain-derived neurotrophic factor in RTT is likely one of the key factors associated with abnormalities in neuronal survival and function, including in key brainstem respiratory nuclei (Katz, 2005; Mironov et al., 2009; Kline et al., 2010; Schmid et al., 2012). Furthermore, loss of Mecp2 expression in astrocytes and microglia appears to play a significant role in the progression of RTT and, of particular relevance, the development of the respiratory and anxiety phenotypes (Maezawa and Jin, 2010; Lioy et al., 2011; Derecki et al., 2012).

\section{Correlation with RTT patient data}

Females with an MeCP2 mutation are typically mosaic, with approximately half of the cells randomly expressing the mutant allele. The heterogeneity of the deletion likely explains the spectrum of breathing abnormalities in RTT patients, which includes periods of slow-deep breathing, hyperventilation, central apnea, breath-holding, and Valsalva and Cheynes-Stokes breathing (Julu et al., 2001; Weese-Mayer et al., 2006). The male mouse model with the uniform deletion expresses only a subset of these patterns. With regards to the occurrence of apnea during sleep versus wakefulness, many RTT clinical studies (Lugaresi et al., 1985; Marcus et al., 1994; Julu et al., 2001) report regular breathing during sleep states, similar to what we observe during earlystage disease in the mouse model. However, there are reports of abnormal respiratory rhythms during sleep in a subset of patients (Rohdin et al., 2007; d'Orsi et al., 2009) that correlate with the later stages of $M e c p 2^{-l y}$ mouse respiratory phenotype. There are also data showing that breathing irregularities emerge during sleep as patient's age (Schlüter et al., 1995).

Heightened anxiety is reported to occur significantly more frequently in RTT than in other forms of mental retardation (Sansom et al., 1993; Mount et al., 2002). We show a clear correlation between the level of anxiety and the breathing instability in the early stage of the mouse respiratory phenotype. Furthermore, anxiolytic agents normalize respiratory pattern in Mecp2 mouse models. This suggests a potential pharmacological intervention in those patients who have clear elevated anxiety and a respiratory phenotype primarily during wakefulness. A recent human study demonstrated that administration of a well-tolerated CRHR1 antagonist diminished anxiety evoked by $7.5 \% \mathrm{CO}_{2}$ exposure (Bailey et al., 2011). The administration of anxiolytics that also act on neuromodulatory systems that are affected in RTT could be advantageous. The challenge is that, because of the mosaic nature of the disorder and potential for age-dependent changes within an individual patient, the specific neuromodulatory imbalances will vary. Longitudinal studies of respiratory patterns during wakesleep states and reflex responses to hypoxia would differentiate between a stable respiratory phenotype and a progressive one attributable to the development of neuronal-glial abnormalities within medullary respiratory nuclei. In addition, there may be a cohort of RTT patients with a particular mosaic of neuronal defects that leads to a central medullary respiratory defect at an early age that cannot be treated effectively with anxiolytics. It will be of interest to incorporate these concepts into future clinical studies of the respiratory phenotype and the strategic development of effective pharmacological therapies.

\section{References}

Abdala AP, Dutschmann M, Bissonnette JM, Paton JF (2010) Correction of respiratory disorders in a mouse model of Rett syndrome. Proc Natl Acad Sci U S A 107:18208-18213. CrossRef Medline

Adachi M, Autry AE, Covington HE 3rd, Monteggia LM (2009) MeCP2mediated transcription repression in the basolateral amygdala may underlie heightened anxiety in a mouse model of Rett syndrome. J Neurosci 29:4218-4227. CrossRef Medline

Axelrod FB, Chelimsky GG, Weese-Mayer DE (2006) Pediatric autonomic disorders. Pediatrics 118:309-321. CrossRef Medline

Bailey JE, Papadopoulos A, Diaper A, Phillips S, Schmidt M, van der Ark P, Dourish CT, Dawson GR, Nutt DJ (2011) Preliminary evidence of anxiolytic effects of the CRF(1) receptor antagonist R317573 in the 7.5\% $\mathrm{CO}(2)$ proof-of-concept experimental model of human anxiety. J Psychopharmacol 25:1199-1206. CrossRef Medline

Blanchard DC, Griebel G, Blanchard RJ (2003) Conditioning and residual emotionality effects of predator stimuli: some reflections on stress and emotion. Prog Neuropsychopharmacol Biol Psychiatry 27:1177-1185. CrossRef Medline

Brady KT, Johnston AL, Cunningham M, Malcolm R (1991) Profiles of hospitalized benzodiazepine abusers. J Psychoactive Drugs 23:71-72. CrossRef Medline

Brankack J, Kukushka VI, Vyssotski AL, Draguhn A (2010) EEG gamma frequency and sleep-wake scoring in mice: comparing two types of supervised classifiers. Brain Res 1322:59-71. CrossRef Medline

Braun S, Kottwitz D, Nuber UA (2012) Pharmacological interference with the glucocorticoid system influences symptoms and lifespan in a mouse model of Rett syndrome. Hum Mol Genet 21:1673-1680. CrossRef Medline

Calvo-Torrent A, Brain PF, Martinez M (1999) Fecal bolus as indicator of stress: effect of predatory stress on sucrose intake and behavior on the plus-maze in male mice. Physiol Behav 67:189-196. CrossRef Medline

Centeno VA, Volosin M (1997) Chronic treatment with desipramine: effect on endocrine and behavioral responses induced by inescapable stress. Physiol Behav 62:939-944. CrossRef Medline

Chahrour M, Zoghbi HY (2007) The story of Rett syndrome: from clinic to neurobiology. Neuron 56:422-437. CrossRef Medline

Chen RZ, Akbarian S, Tudor M, Jaenisch R (2001) Deficiency of methylCpG binding protein- 2 in CNS neurons results in a Rett-like phenotype in mice. Nat Genet 27:327-331. CrossRef Medline

Chen Y, Brunson KL, Müller MB, Cariaga W, Baram TZ (2000) Immunocytochemical distribution of corticotrophin-releasing hormone receptor type-1 (CRF1)-like immunoreactivity in the mouse brain: light microscopy analysis using an antibody directed against the C-terminus. J Comp Neurol 420:305-323. CrossRef Medline

Cobb S, Guy J, Bird A (2010) Reversibility of functional deficits in experimental models of Rett syndrome. Biochem Soc Trans 38:498-506. CrossRef Medline

Dalvi A, Rodgers RJ (1996) GABAergic influences on plus-maze behaviour in mice. Psychopharmacology (Berl) 128:380-397. CrossRef Medline

Derecki NC, Cronk JC, Lu Z, Xu E, Abbott SB, Guyenet PG, Kipnis J (2012) Wild-type microglia arrest pathology in a mouse model of Rett syndrome. Nature 484:105-109. CrossRef Medline

De Vry J, Benz U, Schreiber R, Traber J (1993) Shock-induced ultrasonic vocalization in young adult rats: a model for testing putative anti-anxiety drugs. Eur J Pharmacol 249:331-339. CrossRef Medline

d'Orsi G, Demaio V, Scarpelli F, Calvario T, Minervini MG (2009) Central sleep apnoea in Rett syndrome. Neurol Sci 30:389-391. CrossRef Medline

Fyffe SL, Neul JL, Samaco RC, Chao HT, Ben-Shachar S, Moretti P, McGill BE, Goulding EH, Sullivan E, Tecott LH, Zoghbi HY (2008) Deletion of Mecp2 in Sim1-expressing neurons reveals a critical role for MeCP2 in feeding behavior, aggression, and the response to stress. Neuron 59:947958. CrossRef Medline

Gemelli T, Berton O, Nelson ED, Perrotti LI, Jaenisch R, Monteggia LM (2006) Postnatal loss of methyl-CpG binding protein 2 in the forebrain is sufficient to mediate behavioral aspects of Rett syndrome in mice. Biol Psychiatry 59:468-476. CrossRef Medline

Gray TS, Bingaman EW (1996) The amygdala: corticotropin-releasing factor, steroids, and stress. Crit Rev Neurobiol 10:155-168. CrossRef Medline

Guy J, Hendrich B, Holmes M, Martin JE, Bird A (2001) A mouse Mecp2- 
null mutation causes neurological symptoms that mimic Rett syndrome. Nat Genet 27:322-326. CrossRef Medline

Guy J, Gan J, Selfridge J, Cobb S, Bird A (2007) Reversal of neurological defects in a mouse model of Rett syndrome. Science 315:1143-1147. CrossRef Medline

Guy J, Cheval H, Selfridge J, Bird A (2011) The role of MeCP2 in the brain. Annu Rev Cell Dev Biol 27:631-652. CrossRef Medline

Hagberg B (2002) Clinical manifestations and stages of Rett syndrome. Ment Retard Dev Disabil Res Rev 8:61-65. CrossRef Medline

Julu PO, Kerr AM, Apartopoulos F, Al-Rawas S, Engerström IW, Engerström L, Jamal GA, Hansen S (2001) Characterisation of breathing and associated central autonomic dysfunction in the Rett disorder. Arch Dis Child 85:29-37. CrossRef Medline

Katz DM (2005) Regulation of respiratory neuron development by neurotrophic and transcriptional signaling mechanisms. Respir Physiol Neurobiol 149:99-109. CrossRef Medline

Katz DM, Dutschmann M, Ramirez JM, Hilaire G (2009) Breathing disorders in Rett syndrome: progressive neurochemical dysfunction in the respiratory network after birth. Respir Physiol Neurobiol 168:101-108. CrossRef Medline

Kline DD, Ogier M, Kunze DL, Katz DM (2010) Exogenous brain-derived neurotrophic factor rescues synaptic dysfunction in Mecp2-null mice. J Neurosci 30:5303-5310. CrossRef Medline

Lioy DT, Garg SK, Monaghan CE, Raber J, Foust KD, Kaspar BK, Hirrlinger PG, Kirchhoff F, Bissonnette JM, Ballas N, Mandel G (2011) A role for glia in the progression of Rett's syndrome. Nature 475:497-500. CrossRef Medline

Lugaresi E, Cirignotta F, Montagna P (1985) Abnormal breathing in the Rett syndrome. Brain Dev 7:329-333. CrossRef Medline

Maezawa I, Jin LW (2010) Rett syndrome microglia damage dendrites and synapses by the elevated release of glutamate. J Neurosci 30:5346-5356. CrossRef Medline

Marcus CL, Carroll JL, McColley SA, Loughlin GM, Curtis S, Pyzik P, Naidu S (1994) Polysomnographic characteristics of patients with Rett syndrome. J Pediatr 125:218-224. CrossRef Medline

McGill BE, Bundle SF, Yaylaoglu MB, Carson JP, Thaller C, Zoghbi HY (2006) Enhanced anxiety and stress-induced corticosterone release are associated with increased Crh expression in a mouse model of Rett syndrome. Proc Natl Acad Sci U S A 103:18267-18272. CrossRef Medline

Mironov SL, Skorova E, Hartelt N, Mironova LA, Hasan MT, Kügler S (2009) Remodelling of the respiratory network in a mouse model of Rett syndrome depends on brain-derived neurotrophic factor regulated slow calcium buffering. J Physiol 587:2473-2485. CrossRef Medline

Moretti P, Zoghbi HY (2006) MeCP2 dysfunction in Rett syndrome and related disorders. Curr Opin Genet Dev 16:276-281. CrossRef Medline

Mount RH, Charman T, Hastings RP, Reilly S, Cass H (2002) The Rett Syndrome Behaviour Questionnaire (RSBQ): refining the behavioural phenotype of Rett syndrome. J Child Psychol Psychiatry 43:1099-1110. CrossRef Medline

Neul JL, Zoghbi HY (2004) Rett syndrome: a prototypical neurodevelopmental disorder. Neuroscientist 10:118-128. CrossRef Medline

Nuber UA, Kriaucionis S, Roloff TC, Guy J, Selfridge J, Steinhoff C, Schulz R, Lipkowitz B, Ropers HH, Holmes MC, Bird A (2005) Up-regulation of glucocorticoid-regulated genes in a mouse model of Rett syndrome. Hum Mol Genet 14:2247-2256. CrossRef Medline

Ogier M, Wang H, Hong E, Wang Q, Greenberg ME, Katz DM (2007) Brain-derived neurotrophic factor expression and respiratory function improve after ampakine treatment in a mouse model of Rett syndrome. J Neurosci 27:10912-10917. CrossRef Medline

Paton JF (1996) A working heart-brainstem preparation of the mouse. J Neurosci Methods 65:63-68. CrossRef Medline

Pitkänen A, Savander V, LeDoux JE (1997) Organization of intraamygdaloid circuitries in the rat: an emerging framework for understanding functions of the amygdala. Trends Neurosci 20:517-523. CrossRef Medline

Ren J, Poon BY, Tang Y, Funk GD, Greer JJ (2006) Ampakines alleviate respiratory depression in rats. Am J Respir Crit Care Med 174:1384-1391. CrossRef Medline

Rohdin M, Fernell E, Eriksson M, Albåge M, Lagercrantz H, Katz-Salamon M (2007) Disturbances in cardiorespiratory function during day and night in Rett syndrome. Pediatr Neurol 37:338-344. CrossRef Medline
Roux JC, Villard L (2010) Biogenic amines in Rett syndrome: the usual suspects. Behav Genet 40:59-75. CrossRef Medline

Roux JC, Dura E, Moncla A, Mancini J, Villard L (2007) Treatment with desipramine improves breathing and survival in a mouse model for Rett syndrome. Eur J Neurosci 25:1915-1922. CrossRef Medline

Rudolph U, Crestani F, Benke D, Brünig I, Benson JA, Fritschy JM, Martin JR, Bluethmann H, Möhler H (1999) Benzodiazepine actions mediated by specific gamma-aminobutyric acid(A) receptor subtypes. Nature 401: 796-800. CrossRef Medline

Sakanaka M, Shibasaki T, Lederis K (1986) Distribution and efferent projections of corticotropin-releasing factor-like immunoreactivity in the rat amygdaloid complex. Brain Res 382:213-238. CrossRef Medline

Samaco RC, Fryer JD, Ren J, Fyffe S, Chao HT, Sun Y, Greer JJ, Zoghbi HY, Neul JL (2008) A partial loss of function allele of methyl-CpG-binding protein 2 predicts a human neurodevelopmental syndrome. Hum Mol Genet 17:1718-1727. CrossRef Medline

Sansom D, Krishnan VH, Corbett J, Kerr A (1993) Emotional and behavioural aspects of Rett syndrome. Dev Med Child Neurol 35:340-345. Medline

Santibañez M, Gysling K, Forray MI (2006) Desipramine prevents the sustained increase in corticotropin-releasing hormone-like immunoreactivity induced by repeated immobilization stress in the rat central extended amygdala. J Neurosci Res 84:1270-1281. CrossRef Medline

Schlüter B, Aguigah G, Buschatz D, Trowitzsch E, Aksu F (1995) Polysomnographic recordings of respiratory disturbances in Rett syndrome. J Sleep Res 4:203-207. CrossRef Medline

Schmid DA, Yang T, Ogier M, Adams I, Mirakhur Y, Wang Q, Massa SM, Longo FM, Katz DM (2012) A TrkB small molecule partial agonist rescues TrkB phosphorylation deficits and improves respiratory function in a mouse model of Rett syndrome. J Neurosci 32:1803-1810. CrossRef Medline

Stephenson R, Liao KS, Hamrahi H, Horner RL (2001) Circadian rhythms and sleep have additive effects on respiration in the rat. J Physiol 536:225235. CrossRef Medline

Steriade M, McCormick DA, Sejnowski TJ (1993) Thalamocortical oscillations in the sleeping and aroused brain. Science 262:679-685. CrossRef Medline

Stettner GM, Huppke P, Brendel C, Richter DW, Gärtner J, Dutschmann M (2007) Breathing dysfunctions associated with impaired control of postinspiratory activity in Mecp2-/y knockout mice. J Physiol 579:863-876. CrossRef Medline

Swanson LW, Sawchenko PE, Rivier J, Vale WW (1983) Organization of ovine corticotropin-releasing factor immunoreactive cells and fibers in the rat brain: an immunohistochemical study. Neuroendocrinology 36: 165-186. CrossRef Medline

Vendruscolo LF, Vendruscolo JC, Terenina-Rigaldie E, Raba F, Ramos A, Takahashi RN, Mormède P (2006) Genetic influences on behavioral and neuroendocrine responses to predator-odor stress in rats. Neurosci Lett 409:89-94. CrossRef Medline

Viemari JC, Roux JC, Tryba AK, Saywell V, Burnet H, Peña F, Zanella S, Bévengut M, Barthelemy-Requin M, Herzing LB, Moncla A, Mancini J, Ramirez JM, Villard L, Hilaire G (2005) Mecp2 deficiency disrupts norepinephrine and respiratory systems in mice. J Neurosci 25:11521-11530. CrossRef Medline

Voituron N, Hilaire G (2011) The benzodiazepine Midazolam mitigates the breathing defects of Mecp2-deficient mice. Respir Physiol Neurobiol 177: 56-60. CrossRef Medline

Ward CS, Arvide EM, Huang TW, Yoo J, Noebels JL, Neul JL (2011) MeCP2 is critical within HoxB1-derived tissues of mice for normal lifespan. J Neurosci 31:10359-10370. CrossRef Medline

Weese-Mayer DE, Lieske SP, Boothby CM, Kenny AS, Bennett HL, Silvestri JM, Ramirez JM (2006) Autonomic nervous system dysregulation: breathing and heart rate perturbation during wakefulness in young girls with Rett syndrome. Pediatr Res 60:443-449. CrossRef Medline

Weng SM, Bailey ME, Cobb SR (2011) Rett syndrome: from bed to bench. Pediatr Neonatol 52:309-316. CrossRef Medline

Zanella S, Mebarek S, Lajard AM, Picard N, Dutschmann M, Hilaire G (2008) Oral treatment with desipramine improves breathing and life span in Rett syndrome mouse model. Respir Physiol Neurobiol 160:116121. CrossRef Medline 